\title{
The Development Trends of Fuel Cell Technologies Based on Patent Analysis
}

\author{
Tan Xinyu ${ }^{1}$, Zhang Yingxuan ${ }^{1}$ and Deng Sanhong ${ }^{1,2^{*}}$ \\ ${ }^{1}$ School of Information Management, Nanjing university, 210023, China \\ ${ }^{2}$ Key Laboratory of Data Engineering and Knowledge Services in Jiangsu Province, 210023, China
}

\begin{abstract}
Fuel cells are made from fuel and oxygen. Because of its low pollution, high energy conversion efficiency and high reliability, fuel cell has become the future direction of new energy application, the technological development path in the field of fuel cell research has great significance to the development of technological and energy innovation. Using the patent analysis method, this paper analyses the patent data from Derwent Innovation Index quantitively to study the state of application for patents, core technologies, highly cited patents and the main patentees. It shows that auxiliary device and related methods were a research hotspot in recent years; as the biggest patent holder of fuel cell technologies, Toyota, Honda motor Co. and Nissan motor Co. have an advantage. This paper has discovered some potential problems behind the phenomena and some suggestions are put forward finally.
\end{abstract}

\section{Introduction}

Fuel cell is the most promising power generation technology so far[1]. At present, countries all around the world have invested heavily in the research field of fuel cell, and have formulated relevant policies and plans to strongly promote the development of fuel cell industry. The research into fuel cell industry is mainly done in Japan and the United States. According to Rong Zeng, Zhenghui Zhang and some other scholars [2], the present situation of fuel cell technology development is analysed in detail from the aspects of field distribution, age characteristics, etc.. P.P. Edwards[3]provides a reference for the future development of fuel cell from the angle of policy making; by using citation network analysis, Bart Verspagen [4] studies the fuel cell technology in the United States and finds the technical barriers.

In China, Hou Yuan Yuan [5] revealed the research status of fuel cells in China by analysing the cooperation relationship and technical correlation of fuel cell applicants in China. Lan Ying [6] analysed the overall and partial technical efficiency layout of the fuel cell vehicle patents, and studied the global and major countries' technical hotspots and gaps in the field of fuel cell vehicles.

In the early years, researchers at home and abroad have studied the overall development of fuel cell technology, and there have also been specific research results on the development states of solid oxide fuel cell or hydrogen fuel cell. However, in recent years, few researchers reevaluate the overall development of fuel cells. The technology is changing rapidly, thus studies of eight or nine years ago can no longer accurately describe the present development state of fuel cell industry or predict the trend of the technology. In order to grasp the latest fuel cell industry, this paper is based on Derwent Innovation Index, using the method of patent analysis to explore global fuel cell patent application states, the core technology, important patent holders and main Derwent manual codes.

\section{Data sources and pretreating}

Fuel cells can be divided into five main categories according to electrolyte types: alkaline fuel cell (AFC), phosphoric acid fuel cell (PAFC), molten carbonate fuel cell (MCFC), solid oxide fuel cell (SOFC) and proton exchange membrane fuel cell (PEMFC). In this study, data were obtained from Derwent Innovation Index. To simplify the analysis, TI was used as the search condition to construct the search expression: $\mathrm{TI}=($ fuel cell* $\mathrm{OR} \mathrm{AFC}$ OR MCFC OR PEMFC OR PAFC OR SOFC). The time range is all; a total of 93999 patents documentation were retrieved on July 17, 2019.

After that, according to the $\mathrm{AD}$ (application details) field in Derwent patent data, $\mathrm{R}$ was used to screen out the relevant patents applied from 1979 to 2018, and a total of 92193 pieces of data were obtained. R and Excel 2019 were used for data cleaning and the statistics of several information. Tableau 2019.2 and CiteSpace.5.5.R2 were used for visualization.

\section{Patent analysis}

\subsection{Analysis of The Overall Situation of Fuel Cell Technology}

\footnotetext{
*sanhong@nju.edu.cn
} 
3.1.1 Annual changes in the number of patents. The number of international annual patent applications for fuel cells is counted, and the results are shown in figure 1. After 1998, the total number of patents increased rapidly. From 1979 to 2016, Japan ranked first in total number of patents related to fuel cell technology. The changes in the number of related patent applications in Japan, the United States and China (excluding Taiwan, hereinafter the same) have a similar trend, experiencing a first rise and then fall process. Applications peaked in 2006 and have since fallen back. China started its research and development relatively late. In 2010, its application rate started to increase and ranked first in the world by 2017. This may be attributed to China's high attention and continuous investment in the field of new energy. The UK (GB) has seen a steady decline in applications and has shown little interest in recent years.

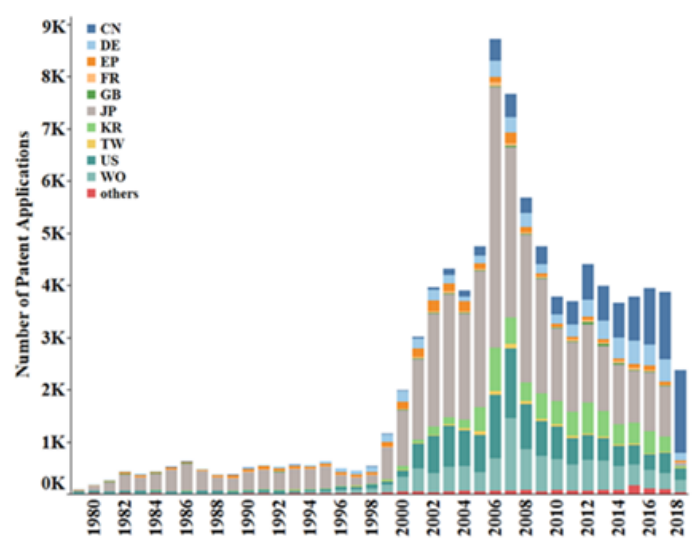

Figure 1. Annual Trend of Patent Number

\subsubsection{Country of origin of patent applications(TOP} 10). The total number of patent applications from 1979 to 2018 is counted. Japan(41351) ranked first in the number of applications, followed by the United States(12259), China(9574) and South Korea(6844). Patent applications from these four regions cover nearly $78 \%$ of the total patent applications. It is noteworthy that Japan and the United States, as the world's precursor and leader in fuel cell technology, applied for more than half of the total number of applications. In addition, the proportion of Korean applications is relatively large, which is mainly due to the mature development in Korean technology industry[9].

3.1.3 Patent lifecycle. Generally speaking, there are four stages in the development of technology: pregnancy, growth, maturity and decay[10]. To study the patent application trend in fuel cell field, we use the number of patent applicants as the horizontal axis, the number of patent applicants as the vertical axis and use the data points representing the specific time to draw the Patent Lifecycle Map(figure 2). Before 1998, it developed slowly and belonged to the pregnancy stage; Growth stage began in 1998, the number of patent applicants and the number of patent applications began to increase significantly; After 2007, the field has entered a mature period. The number of patent applications and the number of patent applications tended to stabilize. There was a slight upward trend in 2012 and then declined slowly. It can be seen that the basic field of fuel cell has been relatively mature, and new breakthroughs are urgently needed.

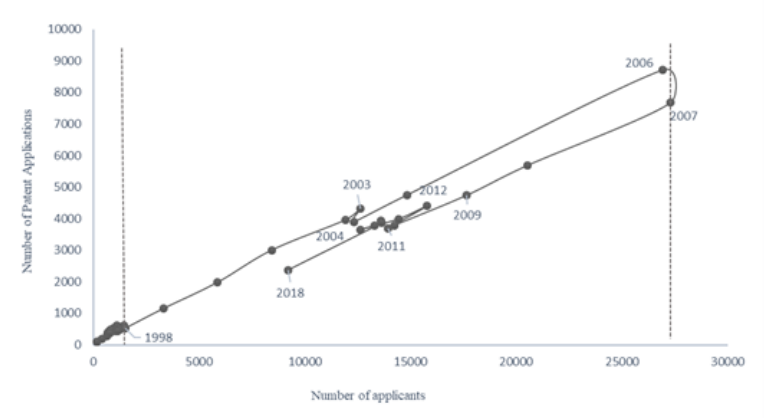

Figure 2. The Technology Life Cycle of Fuel Cell

\subsection{Main Applicants And Their Partnership}

The patentees of fuel cell global patents from 1979 to 2018 are counted and the top 20 patentees with the largest number of patents in the world are corresponded to the corresponding countries. The TOP 20 patentee-country distribution chart is shown in Figure 3. From Figure 3, we can see, Japanese company, Toyota Jidosha Kabushiki Kaisha is far ahead and ranks first with 8170 related patent applications. Toyota Jidosha Kabushiki Kaisha is Worldrenowned automobile manufacturers. It takes the lead in the field of fuel cells mainly due to its development advantages in the field of fuel cell electric vehicle. Secondly, the number of patents owned by Nissan Motor Co Ltd(3726), Honda Motor Co Ltd(3667) and Hyundai Motor Co Ltd(1918) is more than 1500.Among the patentees of TOP 20, 15 are Japanese enterprises. We can see, Japan is in an absolute advantage.

Analysing the top 50 applicants, we found that 47 companies were related to electrical appliances and automotive technology, and two research institutes(Cas Dalian Chem \& Physical Inst, Forschungszentrum Juelich $\mathrm{GmbH}$ )and Commissariat Energie Atomique. Fuel cell can be widely used in automotive engines and various motor power fields as an efficient and clean energy, while research institutes concentrate more on the technology itself, so as to facilitate teaching innovation and so on.

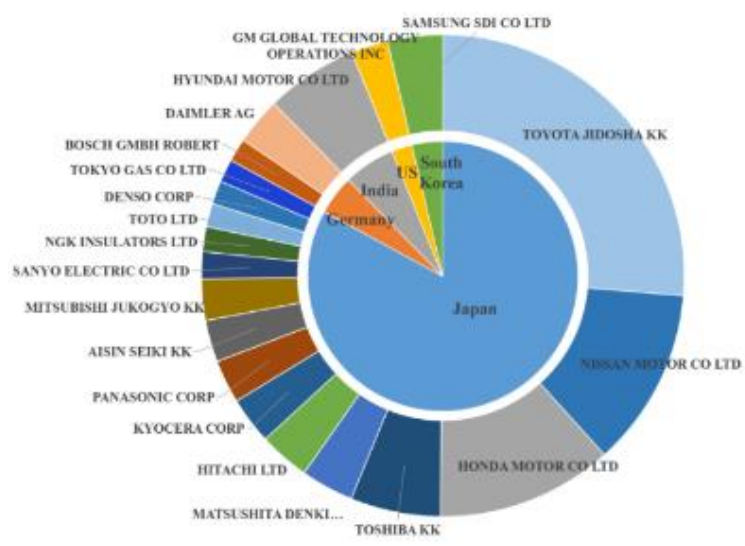

Figure 3. Distribution of Main Patent Applicants 
In addition, according to the distribution of patent applications from 1979 to 2018(Slice Length=, Top 10 per slice),we finds partnerships between major patentees. As we can see in Figure 4, there is close cooperation among patentees.

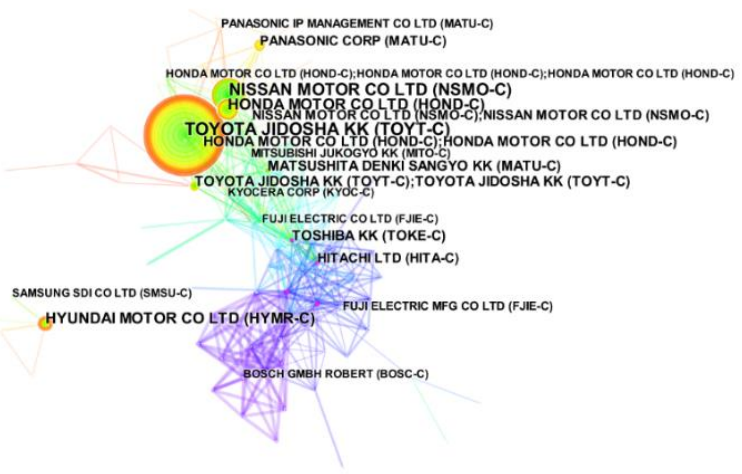

$N=132, E=560$

Figure 4. Cooperation Relationship of the Major Patent Holder

Cooperative projects centred on automobile companies such as Toyota Jidosha Kabushiki Kaisha 、

Nissan Motor Co Ltd 、 Honda Motor Co Ltd, Hyundai Motor Co Ltd, are very common; Toyota Jidosha Kabushiki Kaisha participated in the research and development of 2175 patents, followed by Nissan Motor Co Ltd(912). Overview of Top 10 patentees in the number and proportion of patentee co-operations shows that the companies with more cooperation mainly are Japanese automobile companies, which attach importance to the development of patents in this field patents and has rich patent application experience.

\subsection{Patentable Subject Matter Distribution}

3.3.1 General theme analysis. To overview the evolution of research hotspots in fuel cell patents, we take
Top 20 patents form each slice(Slice Length=2) and draw the timeline view(figure 5). Combining with the corresponding selection of the Top 150 mutation word diagrams and retaining the Top 10 as the representative(figure 6), we can see that, research mainly concentrates on four categories: nuclear fuel rod, fuel cell system, polymer electrolyte fuel cell, fuel cell. Among them, the nuclear fuel rods have the most related research and development categories and the longest duration, but the lowest in the maximum research heat compared with other clustering.

From 1979 to 1998 , many countries invested more in the components, control systems of fuel cell basic generators and fuel cells of common basic types, focusing on X16-C (Fuel Cells And Associated Components), L03E04 (Fuel Cells [General]) and main categories of fuel cell; over time, in the latter half of our chosen time, fuel cell systems, ion exchange membrane fuel cells and related applications have become the focus of research. Among them, X16-E06A1(Electrode Materials), L03H05(Vehicles), A12-E06A(Electrodes For Batteries, Accumulators, Fuel Cells), X16-C(Fuel Cells And Associated Components)are particularly concerned and may have a further development in the future.

In addition, in the 1980s and 1990s, the need for electrical appliances and nuclear energy-related reactions also prompted research in certain field, such as X14B04X(Construction And Other Details), W03A02(Automatic Frequency Control; Band Scanning; Remote Control), K05-B04B(Fuel Element Construction). However, it did not last for long. Innovations in automotive energy in the last two years have also led to new inventions, T01-J07D1(Vehicle Microprocessor System) is especially notable. It can be seen that the need for inventions in other fields will also affect the progress of fuel cell technology to a certain extent, but the scope of impact is relatively small.

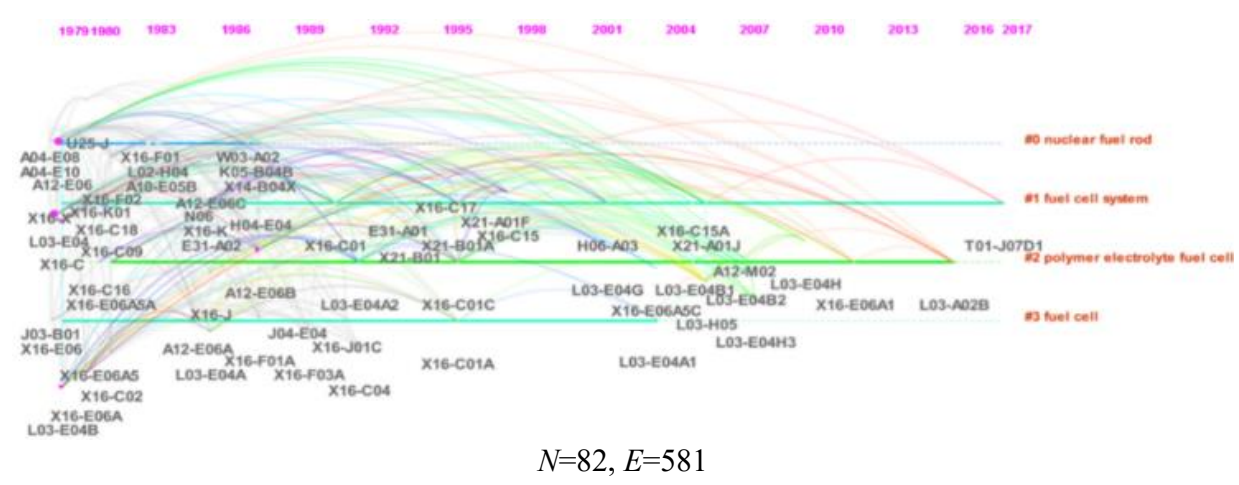

Figure 5. 1979-2018 Derwent Manual Code Timeline 


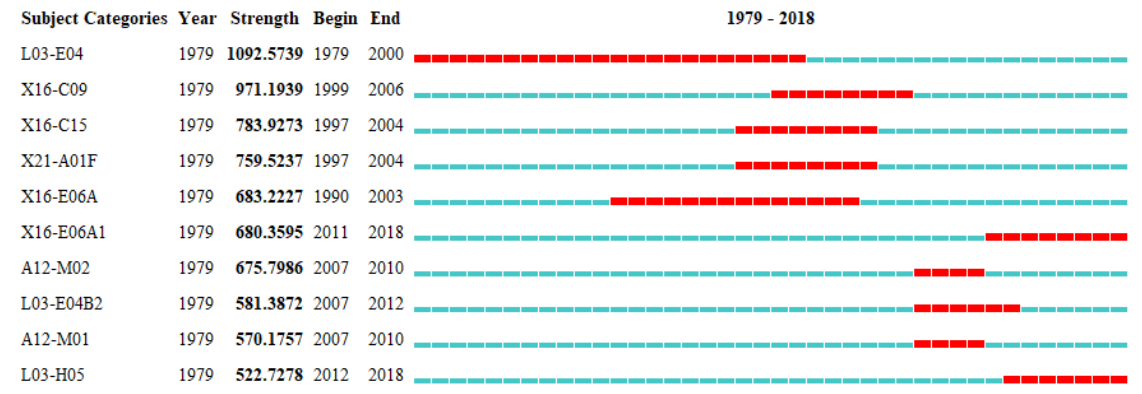

Figure 6. The Burst Derwent Manual Code

3.3.2 Topic analysis of several typical periods. Cooccurrence frequency is the most direct embodiment of hot technology. Co-occurrence graph and timeline view (see figure 8) can fully show the activity and development of each patent category [13]. Taking Derwent manual code as the analysis object, the 1999-2018 period is divided into two periods on average as is shown in figure $5 \sim 6$, and Slice Length $=1$. Top20 is selected to make some cooccurrence cluster graphs and timeline views, so as to explore the hotspot transformation of technological innovation in the fuel cell industry more obviously.

The states of 1999-2008 is presented in figure 7(a) and

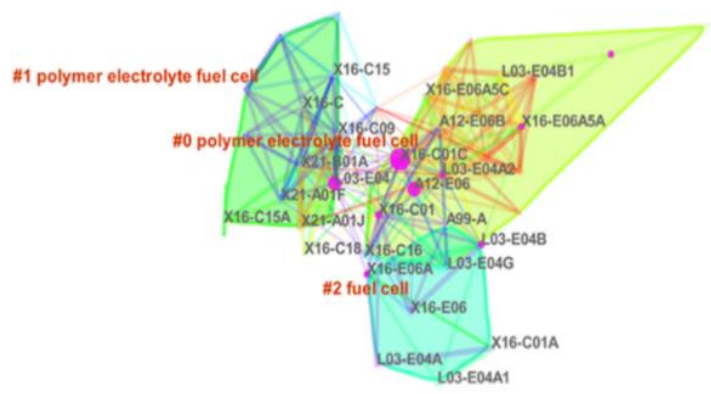

(a)1999-2008 Manual Code Cluster figure 8(a). This is a period of broader innovation than the previous one, but the development of assistive and control systems, as well as solid fuel cells, has not been slowed. Countries begin to apply the technology to life and pay more attention to practical technology applications such as fuel cell vehicle (X21).

The total situation from 2009 to 2018 is shown in figure 7(b) and figure 8(b). On the whole, there is not many changes in the research topic compared with the previous 30 years but the graphs show the vigorous development situation of the research of ion exchange membrane fuel cell and solid fuel cell.

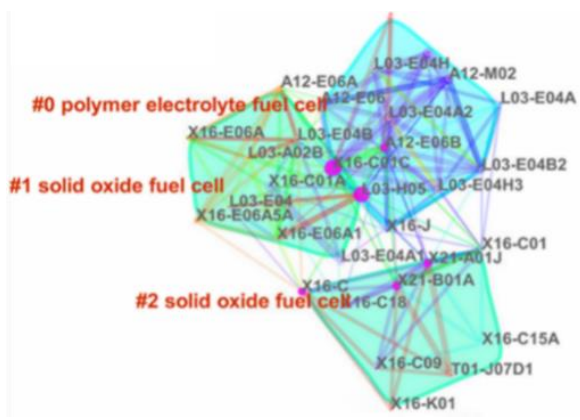

(b)2009-2018 Manual Code Cluster

Figure 7. Derwent Manual Code Cooccurrence Cluster

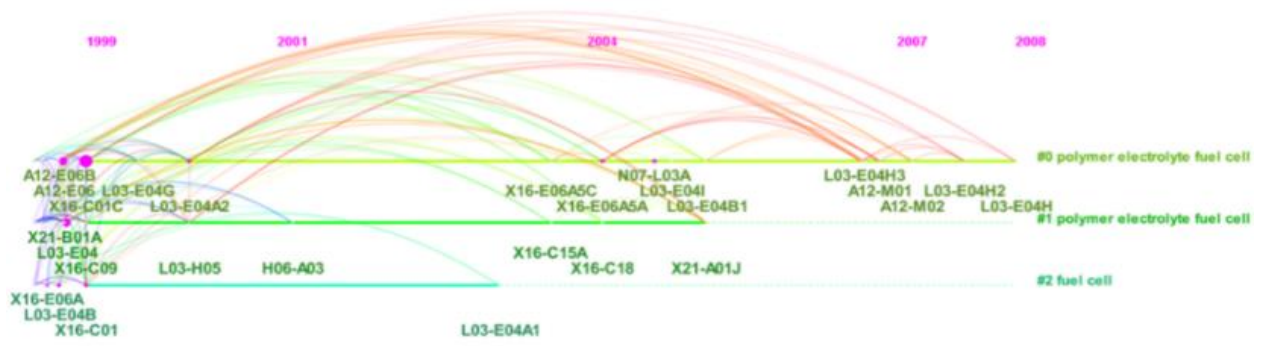

(a) $N=40, E=244$

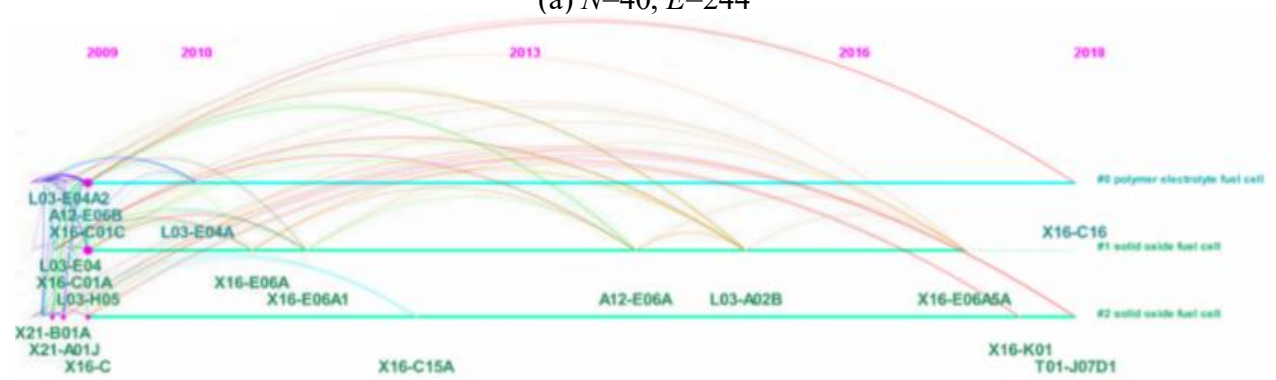

(b) $N=32, E=181$

Figure 8. Derwent Manual Code Timeline 


\section{Conclusion}

Through the analysis of patent data, this paper attempts to grasp the development direction of fuel cell technology and the overall development trend. Through the above analysis, the following conclusions can be drawn:

- Judging from the trend of patent application, 1998 was a turning point. Since 2000 , more attention has been paid to the fields related to fuel cell. The number of patent applications has increased rapidly, and the technology is now in its mature stage.

- From the distribution of the main patentees in the world, Japan, the United States, South Korea account for a relatively high proportion, especially some Japanese automobile enterprises. Meanwhile, some enterprises with the largest number of patent applications also carry out cooperative research and development projects.

- From the perspective of patent topic distribution, the category of fuel cell device and its manufacturing have been explored continuously worldwide, and have been gradually applied when the technology is gradually improved.

Considering the rapid development of fuel cell industry, we put forward some suggestions based on our conclusions. First, strengthen patent awareness, attach importance to patent protection and cultivate patent talents. Second, increasing investment support, improving patent quality, and further optimizing the technological innovation environment[9] can really help. Third, it makes sense to establish a collaborative operation mechanism centred on intellectual property strategic alliance [12]. Finally, it is a good choice to strengthen the close cooperation between industry, learning and research, and carry out collaborative innovation to promote multi-unit cooperation [11].

\section{Acknowledgements}

Our thanks to Derwent Innovation and CiteSpace for providing us with data analysis tools and the innovative ability of the discipline competition under the big data environment of the "13th Five-Year" Experimental Teaching Reform Research Project of Nanjing University (SY201919) for financial support.

\section{References}

1. Fan Huiqing. Electronic Information Materials, Beijing: National Defense Industry Press, 2012.9(in Chinese)

2. Rong Zeng, Varcoe John. Alkaline anion exchange mem-branes for fuel cells-a patent review[J]. Recent Patents on Chemical Engineering,2011,4(2):93-115.

3. Edwards P P, Kuznetsov V L, David W I F, et al. Hydrogen and fuel cells: Towards a sustainable energy future[J]. Energy Policy,2008,36(12):43564362.

4. Bart Verspagen. Mapping technological trajectories as patent citation networks: A study on the history of fuel cell research[J]. Energy Policy,2007,1(10):93115.

5. Hou Yuanyuan. The Distinguishing Methods of Three-Dimensional Patented Technology Life Cycle and Empirical Research[J]. Journal of Intelligence,2013(3):51-54,6(in Chinese)

6. Lan Ying, Zhai Dongsheng, Xia Jun, Gu Ligang. Technical Efficiency Layout Analysis of Fuel Cell Vehicle Based on Patent[J].Journal of Intelligence,2016,35(1):39-44(in Chinese)

7. Yan Chungen, Yuan Hontao, Xu Xiaoyang, Chen Liang. Study on the Technical Status and Development of Chinese Solid Oxide Fuel Cells from the Patent Perspective[J], Journal of Ceramics, 2018,39(6):676-682(in Chinese)

8. Zhang Feng, Liu La, Miao Xiaoming, Fuel Cell Hot Research Areas and Key Technologies: An Empirical Research Based on Patent Data[J], Journal of Intelligence, 2017,36(1):54-58(in Chinese)

9. Zhu Ke, Shi Jixian. Analysis of Patent Application in China in Fuel Cell Technology[J].China Invention \& Patent,2012(1):40-43(in Chinese)

10. Ge Liang. Technology Life Cycle impact on Enerprie technology Development strategy: Taking Method for Manufacturing Graphene of Samsung as an Example[D]. Nanjing Tech University, 2016(in Chinese)

11. Liu Ping, Wang Gang, Li Zhang. Development of Fuel Cell Technology in China Based on Patent Analysis[J].Advanced Materials Industry,2018(5):36-42(in Chinese)

12. Fang Yu. Development Trend Analysis of Hydrogen Fuel Cells Based on Chinese Patents[J].Journal of Changchun Normal University,2017,36(10):62-66(in Chinese)

13. Li Jie, Chen Chaomei. CiteSpace: Text Mining and Visualization in Scientific Literature, Capital Univ of Econ \& Business Publishing House, 2016.1(in Chinese)

14. Jun-ichi Ozaki, Yasuo Imashiro, Development of carbon alloy catalysts for a polymer electrolyte fuel cell,Carbon,,2015,85-444.

15. Gulden Nagmetova, Almira Yagofarova, Kalysh Berdimuratova, Askar Kurmanbayev, Evaluating the performance of electrogenic strains of bacteria in microbial fuel cells, Journal of Biotechnology,2016, 231-S74.

16. Taro Kinumoto, Surface modification of carbonaceous materials and their use in polymer electrolyte fuel cells and hydrogen-air secondary batteries, Carbon, 2014,78:633-634. 